\title{
THE PERCEPTIONS TOWARDS GREEN ENVIRONMENTAL MANAGEMENT DIMENSIONS: A STUDY AT PONTIAN DISTRICT COUNCIL, JOHOR STATE OF MALAYSIA
}

\author{
Rusinah Siron ${ }^{1}$ \\ College of Graduate Studies, National Energy University, Selangor, Malaysia. \\ (Email: Rusinah@uniten.edu.my) \\ Noor Azizun Mohd Saad ${ }^{2}$ \\ Entrepreneurship Centre, National Energy University, Selangor, Malaysia. \\ (Email: NoorAzizun@uniten.edu.my) \\ Mohd Amin Tasripan ${ }^{3}$
}

College of Energy Economics and Social Science, National Energy University, Selangor, Malaysia.

(Email: Amin@uniten.edu.my)

Received date: 05-09-2019

Revised date: 15-09-2019

Accepted date: 13-11-2019

Published date: 10-12-2019

To cite this document: Siron, R., Saad, N. A. M., \& Tasripan, M. A. (2019). The Perceptions towards Green Environmental Management Dimensions: A Study at Pontian District Council, Johor State of Malaysia. Journal of Tourism, Hospitality and Environment Management, 4(17), 01-10.

DOI: $10.35631 / J T H E M .417001$

\begin{abstract}
Environmental management is an important management in building the quality of human life. The management of the green environment, in turn, adds value to efforts to build a more harmonious environment in an effort to prevent pollution related to land, water, fire, and wind. This study takes one step towards identifying people's perceptions of the dimensions of environmental management that affect their lives and their environment. This study focuses on the Pontian district, the Johor state of Malaysia with the objective of this study was to identify the perceptions of Pontian district council staff on the dimensions of environmental management in relation to their work environment as the Pontian district council staff are directly and indirectly involved in green environment management such as waste management and green environmental competency. The survey respondents consisted of 120 staff at the Pontian District Council. The results showed four dimensions of green environment management outcome with the highest percentage agreement is a green organizational climate of 73.5 percent followed by green environment efficiency giving a 72.5 percent agreement percentage followed by green quality of working life 66.8 percent and finally green environmental of waste management by 60.8 percent.
\end{abstract}

Keywords: Green Environment Efficiency, Green Environmental of Waste Management, Green Quality of Working Life and Green Organizational Climate 


\section{Introduction}

The enactment of the Environmental Quality Act (1974) and the establishment of the Environmental Division (now the Department of Environment) the following year was the beginning of the country's direct involvement in environmental management. In line with the Langkawi Declaration of 1989, and the United Nations Conference on Environment and Development (UNCED) in 1992 in Rio de Janeiro, Brazil, the country has taken a deep interest in the environment in the implementation of the country's national development programs as well as in the network international relations. These developments indicate that there is an urgent need to implement the country's position on environmental protection and conservation. Human and environmental interactions and the use of the environment actually involve some important issues of responsibility, management, decision-making and the consequences that are all ethical and moral.

This study focuses on four dimensions of environmental management that include aspects of efficiency namely Green Environmental Efficiency, Green Waste Management, Green Quality of Working Life and Green Organizational Climate. Why were these four dimensions selected for this study? The four-dimensional selection of green environment management is due to:

1. Green environment management requires a good level of practice to ensure that environmental issues can be identified at management level for improvement.

2. Sustainable waste management is essential for the administration of the district administration providing guidance and advice to the community on systematic waste disposal.

3. Green Quality of Working Life is a quality working life setting that promotes well-being and harmony in the workplace.

4. Green Organizational Climate is a focus on work environment that gives employees comfort and satisfaction.

Terms Green is an added value that conveys the sense of well-being, tranquility, harmony and an outlook on the environment that satisfies the quality of life well-being from a variety of physical, mental and social aspects. The four dimensions of green environmental management that are the measurement of perceptions for this study are summarized in Table 1

\section{Table1: Green Environmental Management Dimensions}

\begin{tabular}{|c|c|c|}
\hline Dimensions & Definitions & Sources \\
\hline $\begin{array}{l}\text { Green } \\
\text { Environment } \\
\text { Efficiency } \\
\text { Dimensions }\end{array}$ & $\begin{array}{l}\text { Refers to efficiency is a situation in which the } \\
\text { distribution of environment resources in fit with } \\
\text { society needs and requirements for environment } \\
\text { benefits }\end{array}$ & Mitchell, B. (2002) \\
\hline $\begin{array}{l}\text { Green } \\
\text { Environmental } \\
\text { of Waste } \\
\text { Management }\end{array}$ & $\begin{array}{l}\text { The activities and actions required to manage } \\
\text { waste from its inception to its final disposal. } \\
\text { This includes the collection, transport, treatment } \\
\text { and disposal of waste, together with monitoring } \\
\text { and regulation of the waste management } \\
\text { process. }\end{array}$ & $\begin{array}{l}\text { Adam, W.M. (2009) } \\
\text { Marans, R.W. and Lee, } \\
\text { Y-J. } \\
(1993 / 10)\end{array}$ \\
\hline $\begin{array}{l}\text { Green Quality } \\
\text { of Working Life } \\
\text { Dimension }\end{array}$ & $\begin{array}{l}\text { Quality of work life (QWL) refers to as } \\
\text { satisfaction of the key needs through resources, } \\
\text { activities, and outcomes stemming from } \\
\text { participation in the workplace }\end{array}$ & $\begin{array}{l}\text { Boiral, O. and Paillé, P. } \\
\text { (2012) }\end{array}$ \\
\hline
\end{tabular}




\begin{tabular}{|c|c|c|}
\hline & & $\begin{array}{l}\text { Brio, J.A., Fernandez, } \\
\text { E. and Junquera, B. } \\
(2007) \\
\text { Cherian, J. and Jacob, J. } \\
(2012\end{array}$ \\
\hline $\begin{array}{l}\text { Green } \\
\text { Organizational } \\
\text { Climate } \\
\text { Dimension }\end{array}$ & $\begin{array}{l}\text { Defined as the individual employee's } \\
\text { perception of the psychological impact of the } \\
\text { work environment on his or her own well-being }\end{array}$ & $\begin{array}{l}\text { Del Brío, J., Fernández, } \\
\text { E. and Junquera, B. } \\
\text { (2007) } \\
\text { Govindarajulu, N. and } \\
\text { Daily, B.F. (2004) } \\
\text { Carlopio, J. (1996) }\end{array}$ \\
\hline
\end{tabular}

\section{Research Methodology}

\section{Research Objectives}

Objectives of the study are to identify the perception of employees in Pontian District Council, Johor Bahru State on the four dimensions of green environment management namely Green Environmental Efficiency, Green Environmental Waste Management, Green Quality of Working Life and Green Organizational Climate. Perception level measurement uses the percentage of respondents' agreement on the dimension of the measurement variable.

\section{Research Questions}

The research questions of the study are as follows:

1. What is the agreement level of employees at Pontian District Council on green environmental efficiency practices?

2. What is the agreement level of employees at Johor District Council on green environment of waste management?

3. What is the agreement level of employees at Johor District Council on green quality of working life?

4. What is the agreement level of employees at Johor District Council on green organizational climate?

\section{The Respondents}

The respondents of the study consist of 120 employees in Pontian District Council, Johor State of Malaysia.

\section{Research Instrument}

A questionnaire is the research instrument was based on the adopted version of various researchers and was modified to meet the need and requirement of this research. The pre-test research was conducted by taking sample of 30 respondents consisting of a group of employees from various public organization. The validity of the research questionnaire was used using Alpha Cronbach's measurement and Alpha Cronbach's values are as shown in Table 2. 
Table 2: Alpha Cronbach Value of Green Environmental Management Dimensions

\begin{tabular}{|l|l|c|c|}
\hline Scale & Summary Descriptor & $\begin{array}{c}\text { Number of } \\
\text { Statements }\end{array}$ & $\begin{array}{c}\text { Alpha } \\
\text { Cronbach } \\
\text { Value }\end{array}$ \\
\hline 1. Green environment efficiency & Efficiency & 8 & 0.700 \\
\hline $\begin{array}{l}\text { 2. Green environment of waste } \\
\text { management }\end{array}$ & Waste management & 8 & 0.800 \\
\hline 3. Green quality of working life & $\begin{array}{l}\text { Quality of working } \\
\text { life }\end{array}$ & 31 & 0.650 \\
\hline 4. Green Organizational Climate & $\begin{array}{l}\text { Organizational } \\
\text { climate }\end{array}$ & 34 & 0.750 \\
\hline Total & & 92 & \\
\hline
\end{tabular}

\section{Research Findings}

The presentation of the research findings is based on the percentage of respondents' overall agreement. The Likert Scale of the study were based on five Likert Scale with 1 - Strongly Disagree, 2 - Disagree, 3 - Moderately Agree, 4 - Agree and 5 - Strongly Agree.

The research findings were presented as follows:

1. The findings from the demographic aspects presented their results through the majority of percentage in Table 3.

Table 3: The Demographic Profile of Respondents at Pontian District Council, Johor

\begin{tabular}{|c|l|l|c|}
\hline \multicolumn{3}{|c|}{ State } \\
\hline & Demographic Variable & Pontian District Council \\
\hline 1. & Gender & Majority & Percentage (\%) \\
\hline 2. & Citizenship & Female & 52.8 \\
\hline 3. & Age & Citizen & 98.0 \\
\hline 4. & Education Level & 21-30 years old & 53.6 \\
\hline 5. & Occupational Sector & Degree & 90.8 \\
\hline 6. & Monthly household Income & Government & 67.6 \\
\hline
\end{tabular}

The findings of the demographic-related study indicate that the majority of respondents are women between the ages of 53.6 percent at the age of 21-30 years with 67.6 percent average income level is between RM2000-RM4000 per month.

\section{The Research Questions}

The findings of the study are presented by answering the following research questions:

\section{Research Question 1 - Green Environment Efficiency Dimension}

What is the agreement level of employees at Pontian, Johor District Council on green environmental efficiency practices? 
Table 4: Green Environment Efficiency Dimension

\begin{tabular}{|l|l|c|}
\hline No. & $\begin{array}{l}\text { Item Statements } \\
\text { To my understanding as an employee, the impact of environmental } \\
\text { problems and inefficiency of natural resources will...... }\end{array}$ & $\begin{array}{c}\text { \% } \\
\text { Agreement }\end{array}$ \\
\hline 1. & Be a natural waste for generation & 86.7 \\
\hline 2. & Waste water effluent & 73.3 \\
\hline 3. & Create Local \& regional air pollution & 80.0 \\
\hline 4. & Increase Global pollutants e.g. greenhouse gases & 80.0 \\
\hline 5. & Increase Aesthetic effects (noise, smell, landscape) & 80.0 \\
\hline 6. & Lead to Soil contamination & 80.0 \\
\hline 7. & Lead to Risk of severe accidents & 53.3 \\
\hline 8. & Increase Use of natural resource e.g. energy, water, etc & 46.6 \\
\hline
\end{tabular}

The findings in Table 4 indicate that most employees agree on the item statements related to the green environment problems and inefficiency dimension management with the item statement "Be a natural waste for generation" get the highest agreement with a 86.7 percent agreement while statement "Increase Use of natural resource e.g. energy, water, etc" get the lowest percentage with only 46.6 percent.

\section{Research Question 2 - Green Environmental of Waste Management Dimension}

What is the agreement level of employees at Pontian, Johor District Council on green practices in waste management?

\section{Table 5: Green Environmental of Waste Management dimension}

\begin{tabular}{|l|l|c|}
\hline No. & $\begin{array}{l}\text { Item Statements } \\
\text { To my believe that the government was/will do the waste management } \\
\text { accordingly and specifically on the following: }\end{array}$ & $\begin{array}{c}\text { \% } \\
\text { Agreement }\end{array}$ \\
\hline 1. & Does solid waste separation from the source & 80.0 \\
\hline 2. & Uses recycled materials such as paper for work and in operations & 73.3 \\
\hline 3. & Disposes chemical wastes properly & 40.0 \\
\hline 4. & Has cooperation with recycling companies & 60.0 \\
\hline 5. & Focuses on waste reductions at all functions and operations & 26.7 \\
\hline 6. & $\begin{array}{l}\text { Analyses its internal processes using the right method to minimize } \\
\text { waste }\end{array}$ & 40.0 \\
\hline 7. & Works together with its supply chain partner to eliminate wastes & 93.3 \\
\hline 8. & Cooperates with the community and NGOs in waste management & 73.4 \\
\hline
\end{tabular}

The findings in Table 5 indicate that most employees agree on the item statements related to waste management dimension in Malaysian public institution with the item statement "Works together with its supply chain partner to eliminate wastes" with a 93.3 percent agreement whilst the statement of "Focuses on waste reductions at all functions and operations" get the lowest percentage with only 26.7 percent.

\section{Research Question 3 - Green Quality of Working Life Dimension}

What is the agreement level of employees at Pontian, Johor District Council on green quality of working life? 
Table 6: Green Quality of Working Life Dimension

\begin{tabular}{|c|c|c|}
\hline No. & $\begin{array}{l}\text { Item Statements } \\
\text { To my believed that my workplace management of sustainable } \\
\text { resources are... }\end{array}$ & $\begin{array}{c}\% \\
\text { Agreement }\end{array}$ \\
\hline 1. & Arouse enthusiasm and build optimism on green working practices & 93.3 \\
\hline 2. & Form sound work groups towards green environmental management & 93.3 \\
\hline 3. & Provide motivation towards green environmental management & 53.3 \\
\hline 4. & Persuade employees to perform green environmental management & 80.0 \\
\hline 5. & Makes working on green tasks more pleasant for employees & 73.4 \\
\hline 6. & Treats green team members as equal & 33.4 \\
\hline 7. & Explains how green tasks should be carried out & 13.4 \\
\hline 8. & Decides what and how green management should be done & 100.0 \\
\hline 9. & Maintain definite standards of green work performance & 93.4 \\
\hline 10. & Demonstrate good communication skills in green management & 93.3 \\
\hline 11. & Demonstrate positive leadership qualities in green management) & 40.0 \\
\hline 12. & Develop practical and realistic programs in green management & 60.0 \\
\hline 13. & $\begin{array}{l}\text { Analyse problems in green management and arrive at appropriate } \\
\text { solutions }\end{array}$ & 60.0 \\
\hline 14. & Have the freedom to adapt environmental goals as needed & 93.3 \\
\hline 15. & Treat green team members as equally & 80.0 \\
\hline 16. & Focus both on green task and group performance & 60.0 \\
\hline 17. & Are rewarded for their achievement in green management as a team & 73.3 \\
\hline 18. & Act confidently on their green management recommendations & 46.7 \\
\hline 19. & Communicate personally with each other about green management & 53.3 \\
\hline 20. & $\begin{array}{l}\text { Openly share relevant information on green projects with the whole } \\
\text { team }\end{array}$ & 93.3 \\
\hline 21. & $\begin{array}{l}\text { Are happy with the usefulness of green information shared by } \\
\text { teammates }\end{array}$ & 93.3 \\
\hline 21. & Recognize strengths and weaknesses of individual team members & 86.6 \\
\hline 22. & Contribute to the achievement of the team's environmental & 66.6 \\
\hline 23. & $\begin{array}{l}\text { Develop green management suggestions and contributions of team } \\
\text { members }\end{array}$ & 73.4 \\
\hline 24. & $\begin{array}{l}\text { Acknowledge conflict and work to resolve green management issues as } \\
\text { a team }\end{array}$ & 53.4 \\
\hline 25. & $\begin{array}{l}\text { Acknowledge the green management contributions made by others on } \\
\text { the team }\end{array}$ & 53.3 \\
\hline 26. & Emphasis on long term development of green employee training plans & 80.0 \\
\hline 27. & Frequent evaluation of green employee training programs & 80.0 \\
\hline 28. & Adequate budget for green employee training & 80.0 \\
\hline 29. & Comprehensive green training activities for employees & 100.0 \\
\hline 30. & $\begin{array}{l}\text { Extensive investment of time/ money/ other resources for green } \\
\text { training }\end{array}$ & 100.0 \\
\hline 31. & Continuous green training activities & 86.6 \\
\hline 32. & Incentives for green employee development & 80.0 \\
\hline 33. & Offer training that provides career development opportunity & 66.6 \\
\hline 34. & Develop the comprehensive environmental training policies and & 53.3 \\
\hline
\end{tabular}


The findings in Table 6 indicate that most employees agree on the item statements related to the green quality of working life dimension in Malaysian public institution with the item of statement 'Decides what and how green management should be done", "Comprehensive green training activities for employees" and "Extensive investment of time/money/ other resources for the green training" with a 100 percent agreement while statement 'Explains how green tasks should be carried out" get the lowest percentage with only 13.4 percent.

\section{Research Question 4 - Green Organizational Climate Dimension}

What is the agreement level of employees at Pontian, Johor District Council on green quality of working life?

Table 7: Green Organizational Climate Dimension

\begin{tabular}{|c|c|c|}
\hline No. & $\begin{array}{l}\text { Item Statements } \\
\text { To my belief that the workplace that I worked for... }\end{array}$ & $\begin{array}{l}\% \\
\text { Agreement }\end{array}$ \\
\hline 1. & Will personally contribute to green management work & 100.00 \\
\hline 2. & Feel that working at green management will contribute to my success & 66.7 \\
\hline 3. & $\begin{array}{l}\text { Believe on the green-related work will make good use of my } \\
\text { knowledge and skills }\end{array}$ & 80.0 \\
\hline 4. & $\begin{array}{l}\text { The conducive work environment enables to do my green-related job } \\
\text { effectively }\end{array}$ & 86.7 \\
\hline 5. & Get opportunities to grow and learn new skills in green management & 80.0 \\
\hline 6. & $\begin{array}{l}\text { Satisfied being a part of organization practice in green environmental } \\
\text { management }\end{array}$ & 66.7 \\
\hline 7. & $\begin{array}{l}\text { Motivated towards practicing green environmental management at } \\
\text { work }\end{array}$ & 60.0 \\
\hline 8. & $\begin{array}{l}\text { Regularly let me know what is expected of me in doing my green } \\
\text { work effectively }\end{array}$ & 93.3 \\
\hline 9. & Provide the resources to do my green job effectively & 86.7 \\
\hline 10. & $\begin{array}{l}\text { Give me the individual help and support I need to do my green job } \\
\text { effectively }\end{array}$ & 66.6 \\
\hline 11. & $\begin{array}{l}\text { Offer me opportunities to grow and learn green environmental } \\
\text { management skills }\end{array}$ & 26.6 \\
\hline 12. & Give supportive feedback on the green job that I do & 93.4 \\
\hline 13. & Help me solve environmental problems at work & 93.4 \\
\hline 14. & Talk to the superior about work on green work & 73.4 \\
\hline 15 . & $\begin{array}{l}\text { Employees keep informed of environmental issues that affects } \\
\text { employee interest }\end{array}$ & 93.4 \\
\hline 16. & Encourage employees to speak up and voice their opinions frankly & 66.6 \\
\hline 17. & Allow employees to channel their grievance on environmental issues & 86.7 \\
\hline 18. & $\begin{array}{l}\text { Allow employees to be optimistic about the future of this } \\
\text { organization }\end{array}$ & 80.0 \\
\hline 19. & $\begin{array}{l}\text { Make employees proud of the organization's green environmental } \\
\text { management }\end{array}$ & 40.0 \\
\hline 20. & $\begin{array}{l}\text { Encourage employees' spirit towards making the organization's } \\
\text { green success }\end{array}$ & 40.0 \\
\hline 21. & Employees keep informed of their latest environmental issues & 20.0 \\
\hline 22. & Will personally contribute to green management work & 100.00 \\
\hline
\end{tabular}




\begin{tabular}{|c|l|c|}
\hline 23. & $\begin{array}{l}\text { Working at green management will contribute to my success at the } \\
\text { workplace }\end{array}$ & 66.7 \\
\hline 24. & $\begin{array}{l}\text { Believe on the green-related work make good use of my knowledge } \\
\text { and skills }\end{array}$ & 80.0 \\
\hline 25. & $\begin{array}{l}\text { Feel that convenient physical work environment enables me to do my } \\
\text { green-related job effectively }\end{array}$ & 86.7 \\
\hline 26. & Get opportunities to grow and learn new skills in green management & 80.0 \\
\hline 27. & Give supportive feedback on the green job that I do & 93.4 \\
\hline 28. & Help me solve environmental problems at work & 93.4 \\
\hline
\end{tabular}

The findings in Table 7 indicate that most employees agree on the item statements related to the green organizational climate dimension in Malaysian public institution with the item statement 'Will personally contribute to green management work" get the highest agreement with a 100 percent agreement while statement 'Offer me opportunities to grow and learn green environmental management skills' get the lowest percentage with only 26.6 percent.

\section{Recommendation}

Based on the findings of the study, several suggestions have been put forward that can serve as a guide and service to the improvement of the Pontian District Council in particular on the four dimensions of green environmental management in the study. The results of this study can also serve as a guide for other district councils throughout Malaysia to practice or are in the process and to carry out green environment management at work

\section{Green Environment Efficiency Dimensions}

For the Green Environmental Efficiency dimension, the Pontian District Council is enhancing efforts to manage natural cycle outcomes to reduce land, water, fire and wind pollution issues in the district environment. This should be done with effort and enforcement through informative information, education, health promotion and teaching on the importance of energy saving.

\section{Green Environment of Waste Management}

For Green environmental waste management, the proposal is to focus on enforcement efforts for waste materials such as rubbish, materials, dispose chemicals and other waste that are systematically classified as recycle bins for cans, papers and waste materials. It also makes the waste system cleaner, tidy and moral education for members of the public to dispose of waste as much as the Japanese people is very well known for its cleanliness through civic minded conduct in cleaning and supporting clean environment.

\section{Green Quality of Working Life}

For the green quality of working life, the focus of the recommendations is on building a wellbeing and harmony in the workplace with a range of efforts including strengthening a work environment conducive to greenery scenery and physical resources, less paper use and environmentally friendly office equipment. In addition, management leadership must be sincere in practicing harmonious work environment management with support for employees and work groups on green management. The vision and mission of the organization must move in line with green management. Employees should be given the confidence to carry out their duties with the supervision of knowledgeable and skilled managers in green management. With this the quality of working life is well established and the atmosphere of harmony is 
established. Workers can feel the green quality of working life more efficiently in the workplace.

\section{Green Organizational Climate}

For the green organizational climate, suggestions for maintaining a good working environment are through building skills that relevant to green management, strengthening the green workforce by avoiding work group conflict through clear and open communication. In addition, positive and proactive involvement of work groups and individuals in any green management activity can have a productive impact on building a working spirit in managing a harmonious and prosperous environment for a progressive green work environment.

The conclusion is that green environmental management can only be practiced effectively if everyone in the organization has the opportunity and space to develop good green management programs through positive aspects of cooperation, commitment, leadership and warmth in the workplace to build a truly green working group as it can truly contribute to green management initiatives and strategies.

\section{Acknowledgement}

We would like to express the deepest appreciation to Ministry of Higher Education (MOHE) Malaysia for funding this research under FRGS Grant project code 201601339FRGS entitled "Developing The Rating System Model for Assessing The Green Environmental Management for Malaysian Public Organizations" The authors would like to thank MOHE (Ministry of Higher Education) for the support upon completion of this research.

\section{References}

Adams, W. M., (2009). Green Development: Environment and Sustainability in a Developing World, 3rd Ed, Routledge Publication.

Boiral, O. (2009). Greening the corporation through organizational citizenship behaviors. Journal of Business Ethics, 87, 221-236.

Boiral, O. and Paillé, P. (2012) 'Organizational citizenship behaviour for the environment: Measurement and validation', Journal of Business Ethics, Vol. 109, No. 4, pp.431-446.

Brio, J.A., Fernandez, E. and Junquera, B. (2007) 'Management and employee involvement in achieving an environmental action based competitive advantage: An empirical study', International Journal of Human Resource Management, Vol. 18, pp.491-522.

Carlopio, J. (1996) 'Construct validity of physical work environment satisfaction Questionnaire', Journal of Occupational Health Psychology, Vol. 1, pp.330-344.

Cherian, J. and Jacob, J. (2012) 'A study of green HR practices and its effective implementation in the organization: A review', International Journal of Business and Management, Vol. 7, pp.25-33.

Del Brío, J., Fernández, E. and Junquera, B. (2007) 'Management and employee involvement in achieving an environmental action based competitive advantage: An empirical study', International Journal of Human Resource Management, Vol. 18, No. 4, pp.491-522.

Florida, R. and Davison, D. (2001) 'Gaining from green management: Environmental management systems inside and outside the factory', California Management Review, Vol. 43, No. 3 pp.64-84.

Govindarajulu, N. and Daily, B.F. (2004) 'Motivating employees for environmental improvement', Industrial Management and Data Systems, Vol. 104, No. 4, pp.364-372. 
Kodwo, M., Kwasi.O.D., Zsofia Kadar., Bernadr F.N and Moses Y.M. (2015). Municipal slod waste characterization and quantification as a measure towards effective waste management in Ghana. Waste Management, Vol. 46, December, pg 15-27.

Marans, R.W. and Lee, Y-J. (1993/10) 'Linking recycling Behaviour to waste management planning: A case study of office workers in Taiwan', Landscape and Urban Planning, Vol. 26, Nos. 1-4, pp.203-214. http://hdl.handle.net/2027.42/30543.

Russo, M., Shteigman, A., and Carmeli, A. (2015). Workplace and family support and work life balance: Implications for individual psychological availability and energy at work. The Journal of Positive Psychology, 9760, pg 1-16.

Ronda, L., Lopez A.O. and Goni-Legaz, S. (2016). Family friendly practices, high performance work practices and work family balance: How do job satisfaction and working hours affected this relationship? Management Research: The Journal of the Iberoamerican Academy of Management, 14(1), page 2023.

Subramaniam, G., Tan.P.C., Maniam, B., and Ali, E. (2013). Workplace Flexibility, Empowerment and Quality of Life. Procedia-Social and Behavioral Sciences, 105, pg 885-892.

Shafique K.MA., Jianguo Du., Ali M., Saleem S. and Usma Muhammad. (2019). Interrelations between climate and organizational environmental citizenship behavior: A moderated mediation model. Frontiers in Psychology, August. https://doi.org/10/3389/fpsyg.2019.01977. 